\title{
Forced Migrants in Serbia: Refugees and Internally Displaced Persons-Facts and Figures, Coping Strategies, Future
}

\author{
MirJana Bobic
}

\section{Abstract}

The paper deals with refugees and internally displaced persons (IDPs). Considering their numbers, Serbia is the first in Europe and fourteenth on the globe. Their destiny is not only a tragic epilogue to the political dissolution of the former Yugoslavia, but also to the breakdown of the common dream of "Yugoslav" nationality (which was meant to be a "melting pot" of various nations, ethnic groups, and religions). Unfortunately, due to the specific strategy of nationstate building based on ethnic cleansing, refugees were one of the direct objectives of civil wars taking place in the 1990s. At the same time, massive floods of IDPs were instigated by the bombing campaign of Kosovo and Metohija conducted by the NATO alliance in 1999.

Having come to Serbia, the majority of both refugees and IDPs who are ethnic Serbs have attained all the features of minority groups. The reasons for their social exclusion must be discussed in terms of their exceptionally low social position, high levels of unemployment and poverty, and lack of social inclusion. Moreover, it must be taken into account that contemporary Serbia faced many unresolved political challenges, delayed accession to the EU, secession of Kosovo and Metohija in 2008, hardships in establishing a market economy and liberal democracy since 2000, and economic deprivation, all of which were accompanied by poor social services.

Serbian authorities adopted four major action plans targeted at forced migrants.

However, the main challenges to their applicability stem from lack of institutional capacities, ineffective implementation of development strategies, and limited resources.
Résumé

La Serbie occupe le premier rang en Europe et le quatorzième rang sur terre parmi les pays ayant le plus de réfugiés et de déplacés internes. Leur destin n'est pas seulement l'épilogue tragique de la dissolution politique de l'ex-Yougoslavie, mais aussi de la fin du rêve commun d'une nationalité "yougoslave " (censée être un "melting pot " de différentes nations, groupes ethniques et religions). Malheureusement, en raison d'une stratégie de construction d'État-nation fondée sur le nettoyage ethnique, les réfugiés ont été l'un des objectifs directs des guerres civiles se déroulant dans les années 1990. En même temps, un massif afflux de personnes déplacées a été suscité par la campagne de bombardement menée par l'OTAN au Kosovo-et-Métochie en 1999.

Venue en Serbie, la majorité des réfugiés et des déplacés internes Serbes ethniques ont pourtant atteint toutes les caractéristiques des groupes minoritaires. Les raisons de leur exclusion sociale doivent être examinées en fonction de leur rang social exceptionnellement bas, de taux de chômage et de pauvreté élevés et d'une absence d'inclusion sociale. En outre, il faut prendre en considération les nombreux défis politiques non résolus qui confrontent la Serbie contemporaine, le retardement de son adhésion à l'Union européenne, la sécession du Kosovo-et-Métochie en 2008, les difficultés à établir une économie de marché et instaurer la démocratie libérale depuis 2000 et, enfin, des privations économiques, le tout accompagné par des services sociaux inadéquats.

Les autorités serbes ont adopté quatre importants plans d'action destinés aux migrants forcés. Toutefois, les principaux défis à leur applicabilité proviennent d'un manque de capacité institutionnelle, d'une mise en cuvre inefficace de stratégies de développement et d'un manque de ressources. 


\section{Introduction}

According to a report in 2009 by the United Nations High Commissioner on Refugees (UNHCR), contemporary Serbia hosts the largest number of refugees and internally displaced persons in Europe (and is ranked fourteenth on the globe). Besides them, there are a great number of victims of transit trafficking and smuggling across the borders, consisting predominantly of women, children, and young adults. Furthermore, the greatest portions of asylum seekers in the EU come from Serbia, together with returnees, who had fled to the EU (mostly Germany) during the nineties and are at the moment in the process of readmission. Many young, educated people, among whom there is a growing number of females, strive to move to the West, in search of better living conditions and employment opportunities. One of the greatest obstacles to the management of migration flows derives from the fact that Serbia lacks a common, harmonized visa regime which would establish stable relations with other states (unrestricted mobility of people, goods, and capital).

Refugees from ex-Yugoslavia and internally displaced persons from Kosovo and Metohija are the focus of this paper. They have been arriving in Serbia ever since 1992 (in the case of refugees) ${ }^{1}$ and since the bombing campaign of NATO forces in 1999 and terrorist attacks of ethnic Albanians against Serbs and other non-Albanians at Kosovo in 2004 up to nowadays (in the case of IDPs).

Refugees are the tragic epilogue to the collapse not only of the political and socio-economic system, but to the dream of the unifying Yugoslav nation. Disintegration of the exYugoslavia occurred as a concomitant of the fall of Berlin Wall and thus the breakdown of the Soviet Union in the last decade of the twentieth century. While the countries of central and Eastern Europe experienced peaceful social transition and state disintegration, the former Yugoslavia had undergone a process of enormous breakdown or "social explosion" that was reflected in the sanguinary civil war drama of 1992-1995. Disintegration of the former federal state resulted in the creation of new, autonomous states and entities, with concomitant enormous flows of forced migrants. ${ }^{2}$ Political elites were pursuing their dream of national states based on "blood and soil" by, inter alia, instigating large migrational flows and assimilation of the rest of the population. The civil wars that broke out in Croatia and Bosnia and Hercegovina were inspired by a romantic ideology of "pure nation" (the so-called "eastern model of nation building," 3 and, therefore, ethnic cleansing was one of the means to meet that end. In other words, these circumstances explain why the flood of refugees was one of the direct political and war objectives in the 1990s in the Balkans.
Consequently, refugees of Serb origin flooded to the region of the Republic of Serbia. Not only did they represent forced migrants, who fled from surrounding war zones, but they were the cruel testimony to the failed war adventures of the previous authoritarian political regime of Milosevic as well. However, regardless of what country would receive them, they would end up being marginalized, having to share the destiny of other minority groups (the poor, the elderly, minor ethnic groups, Roma, the disabled, etc.). Over time, the quality of their lives has been improving gradually. However, the pace of improvement has been very slow, because Serbia is experiencing painful and stalled socio-economic transformation, along with coping with a huge army of impoverished, unemployed, and socially disadvantaged individuals. Thus, the refugees are bound to pay the double price of social exclusion: the part of the general price of social transition burdening all members of society plus their own specific price. ${ }^{4}$

This paper is based on some general theoretical considerations of (forced) migrations. The main foundation consists of the theory of "push and pull" factors, created by Donald Bogue as well as on relevant considerations of the multiple factors, which are intertwined and act as determinant factors. ${ }^{5}$ The study of migratory flows is necessarily interdisciplinary, thus integrating various scientific standpoints of sociology, psychology, geography, law, political science, and economy.

Methodology is tailored for the specific purpose of this article. Its main goals are: (1) general description of refugees and IDPs; (2) some basic socio-economic analysis of these groups, and (3) review of current political solutions. Main sources consist of: demographics, secondary analysis of empirical findings on refugees and IDPs, and an overview of political solutions.

\section{Main Concepts and Definitions}

As David J. Whittaker states, ${ }^{6}$ there are more and more people moving around the globe than ever before in recorded history. Some estimates say that since 1945 some 50 to 60 million people have left their homes either voluntarily or involuntarily. Europe in the 1950s, Africa in the 1960s, Asia in the 1970s and 1980s, and once more Europe, especially since the 1990s, were the so-called "zones of anguish," from which people have flooded. Those are the victims of persecution and conflict, who have been seeking safety and opportunities out of their country of origin. These groups are so-called genuine refugees. However, they may also be the victims of environmental degradation, while some are displaced within their own land (so-called internally displaced persons). Other groups of forced migrants are victims of wars and ethnic cleansing. Many people are unable to escape, and

(C) Mirjana Bobic, 2009. This open-access work is licensed under a Creative Commons Attribution-NonCommercial 4.0 International License, which permits use, reproduction and distribution in any medium for non-commercial purposes, provided the original author(s) are credited and the original publication in Refuge: Canada's Journal on Refugees is cited. 
are therefore holed up in temporary camps, while still others flee abroad, becoming illegal immigrants.

It is a fact that an ongoing process of globalization is making the world a smaller place while at the same time squeezing time and space due to faster and cheaper transportation and movement from one country to another, from one continent to another.

According to the same author, there are at least 17 million people in transit nowadays, seeking some form of asylumover 6 million in Asia, 4.2 million in Africa, and 4.2 million in Europe. It is very likely that half of these unfortunates are women and children.

The existence of numerously diverse moves of forced migrants opens up a discussion on various definitions and relevant notions. The UN Convention relating to the Status of Refugees in 1951 defined the term "refugee" with the meaning that is still being used today:

A person who is outside his/her country of nationality or habitual residence; has a well-founded fear of persecution because of his/ her race, religion, nationality, membership of a particular social group or political opinion; and is unable or unwilling to avail himself/herself of the protection of that country, or to return there, for fear of persecution.?

The term "persecution" itself is not legally defined, but is generally based on persistent and consistent patterns of abuse, intervention, and intolerance.

Internally displaced persons are:

persons or groups of persons who have been forced or obliged to flee or to leave their homes or places of habitual residence, in particular as a result of or in order to avoid the effects of armed conflict, situations of generalized violence, violations of human rights or natural or human-made disasters, and who have not crossed an internationally recognized State border. ${ }^{8}$

\section{Setting the Stage: Some Basic Demographic Features}

The first census on refugees and war-affected population in Serbia was conducted in 1996 by UNHCR. According to it, there were 617,728 individuals registered in Serbia. After a while, a vast majority have either obtained citizenship of the Republic of Serbia $(143,200)$ or returned to their countries of origin $(144,000)$. A total of 22,400 have resettled to third countries.

If we pay attention to the period 1996-2007, the evidence clearly documents the decreasing trend of refugees (Table 1). In particular, the last UNHCR report from 2007 demonstrates that their volume is 6.3 times lower than that registered in 1996. It is, however, an unresolved dilemma whether the data conceal the empirical reality. In other words, is the reduction in their overall number the outcome of the cancellation of their humanitarian status instead of their full integration into the local society? Refugees were offered three options for a permanent solution of their legal status: (1) return to the countries they were forced to leave; (2) integration into the local community (Serbia); and (3) emigration. As we shall show later, many of those who decided to return were denied their civil rights in Croatia and Bosnia and Hercegovina, due to the hostility of the local population, unresolved tenancy and property rights, and so forth. The second group, who was willing to integrate in the host society, applied for and in many cases received Serbian citizenship. Unfortunately, this did not automatically result in the improvement of their overall conditions. Many of them joined the pool of unemployed citizens (the unemployment rate in the country is nearly 30 per cent), thus lacking social security and other social services (health, education, public transportation, etc.).

\begin{tabular}{||c|r|r|r||}
\hline \hline \multicolumn{4}{|c|}{ Table 1. Refugees, Serbia, 1996-2007 } \\
\hline Year & $\begin{array}{c}\text { Refugees and } \\
\text { war affected } \\
\text { persons }\end{array}$ & $\begin{array}{c}\text { Total } \\
\text { population }\end{array}$ & $\begin{array}{c}\text { Share of } \\
\text { refugees and } \\
\text { war affected } \\
\text { persons (in \%) }\end{array}$ \\
\hline 1996 & 617728 & $9778991^{*}$ & 6,3 \\
\hline 2002 & 379135 & 7498001 & 5,1 \\
\hline 2005 & 139195 & 7440769 & 1,9 \\
\hline 2007 & 97700 & 7397651 & 1,3 \\
\hline
\end{tabular}

Note: ${ }^{*}$ in 1996 Serbia included the territory of Kosovo and Metohija

Source: UNHCR census and statistics for 1996, 2005, and 2007, respectively; Census of Serbian population Beograd: SZS, 2002; Izbeglički korpus u Srbiji, prema podacima popisa stanovništva 2002, (Refugee Corpus in Serbia) Ministarstvo za ljudska i manjinska prava Srbije i Crne Gore i Republički zavod za statistiku i informatiku Srbije, 2004; <http://webrzs.statserb.sr.gov.yu/ axd/god.htm>

\section{Gender and Age Distributions}

According to the last figures (2007) one may conclude that females outnumber males. The workforce contingent (age 18-59) prevails, but among them, males are more represented. One-third of the total are the elderly, mostly females, and the share of babies and the youth (age $0-17$ ) is 11.3 per cent. 


\begin{tabular}{|c|c|c|c|c|c|c|}
\hline age & M & $\%$ & $F$ & $\%$ & Total & $\%$ \\
\hline $0-4$ & 195 & 0.2 & 196 & 0.2 & 391 & 0.4 \\
\hline $5-11$ & 2057 & 2.1 & 1964 & 2.0 & 4021 & 4.1 \\
\hline $12-17$ & 3416 & 3.5 & 3199 & 3.3 & 6615 & 6.8 \\
\hline $18-59$ & 31605 & 32.4 & 27204 & 27.9 & 58809 & 60.2 \\
\hline $60+$ & 10202 & 10.4 & 17634 & 18.1 & 27836 & 28.5 \\
\hline Total & 47475 & 48.6 & 50197 & 51.4 & 97672 & 100 \\
\hline
\end{tabular}

Source: $<$ http://www.unhcr.org.yu/utils/File.aspx?id=237> (accessed October 2009).

\section{Cultural, Social end Economic Capital}

The last census data ${ }^{9}$ indicates that human/cultural capital of refugees is more favourable in comparison to the general Serbian population, in terms of their completed secondary and higher education. ${ }^{10}$

Regarding socio-economic status of the total refugee population, the employed are dominant (47 per cent), followed by the dependant (37.9 per cent) and those with a personal income-the retired (14.7 per cent). ${ }^{11}$ Slightly less than half of the non-self-supporting persons are women (47.3 per cent). Compared to the general population, refugees have slightly higher rates of employment, a fact that could be explained by their higher subsistence risks and their need to rapidly accommodate to new environments.

The share of refugees with a personal income is, however, lower compared to the general population, due to the problems of pension transfers from the ex-Yugoslav republics. This explains the higher ratio of non-self-supporting persons in the refugee population. To the contrary, refugees have a less advantageous employment structure compared to the general population. Among the active population in Serbia, the employed (78.53 per cent) largely outnumber the unemployed (21.47 per cent). In the refugee population, the respective ratios are 64.2 per cent and 35.8 per cent. This fact could be explained as a result of the great difficulties in finding a job and by a so-called "fluctuating pattern of the working career" (frequent changing of jobs, moonlighting, and losses of jobs). It is also the argument for their social exclusion. As for the professional structure, the majority of refugees work in the service industry and trade (16.2 per cent); followed by skilled workers and technicians (15.1 per cent) and then those performing simple, unqualified work (12.2 per cent). And last, but not least, although the majority of refugees come from the villages, most of them settled in Serbian urban zones. This means that forced migration imposed a forced deruralization of the immigrants. ${ }^{12}$

One recent non-representative survey conducted among the working-age population of refugees (age 15-64) ${ }^{13}$ showed higher activity and employment rates among them compared to the general Serbian population in the same age group. It also demonstrated that the unemployment rate among forced migrants is ten percentage points higher (30.6 per cent compared to 20.8 per cent in the general Serbian work force). The refugees not only have higher proactive strategies in terms of their crude employment rate, but they also outnumber in the shares of entrepreneurs and self-employed. But, at the same time, some one-third are engaged in informal activities. They are compelled to start small businesses on their own, for they lack assistance of the state and its National Employment Agency. Income generating projects, implemented by both government and nongovernmental sectors, are neither transparent nor available to them, so refugees can hardly opt for resources as well as for application. That also makes the doors wide open to corruption and delivering grants to those who have already established their firms.

Other results point to the fact that despite their greater human capital, many refugees work below their qualifications: one out of four with a university diploma works as a highly skilled or skilled worker in the informal economy.

They are also under pressure of combining several jobs, with every third refugee taking an additional job on a regular basis. They mostly work in construction, catering, taking care of the elderly, and housekeeping.

Beside demonstrated willingness to work, refugees are shown to be more flexible in the labour market, in terms of readiness to take part in activities beyond usual working hours, without a contract, or in the private sector. They are willing to perform any paid job regardless of their educational level as well as to moonlight. However, they are reluctant to change their place of residency in case of another job offer. Women also demonstrated strong proactive orientations.

Thus, we can conclude, while the human and social capital are either relatively high or are increasing over time, the economic capital, conversely, remains rather low. The main reason is the very fact that the refugees' properties were left behind them in their former places of residence (Croatia and Bosnia). Only 20 per cent of them managed to preserve or repossess their property. Moreover, the overall household expenditure (food, clothing, hygiene items, etc.) is some 50 per cent higher compared to the general population. The composite index of wealth (constructed as the aggregation of assets, expenditure, and income) clearly demonstrates that 10 per cent of these households are definitely poor, some 49 
per cent have a low wealth score (with a high poverty risk), while 27 per cent have medium, 11 per cent high, and 3 per cent very high scores.

According to the research on social capital, it should be stated that inquiries conducted in 1990s in Serbia ${ }^{14}$ have shown a low level of informal social networks both within the refugee group and with the host population. Moreover, analyses of the social position of refugees and the general quality of their life have clearly shown their social system inhibition, i.e. their withdrawal to the margins of social life or to the bottom of the social scale, by political and legal means, media, and everyday behaviour of the domestic population. The empirical findings report that refugees suffer feelings of resignation, depression, and isolation ${ }^{15}$ Social capital was, thus, very sporadic, restricted to their fellow friends and acquaintances. The ties were based on a common dwelling, leisure time, nurturing children, and the elderly. They either dreamed of returning to homelands or finding ways to permanently reside in Serbia. ${ }^{16}$ But, as time went by, during the last fourteen years, these individuals have been compelled to surpass various obstacles in their everyday life, which resulted in enhancing their social capital.

The most important occasions when a person utilizes assets of social capital are when searching either for a job or for health treatment. Informal networks of reciprocity consist mainly of friends and relatives ("bonding social capital"). ${ }^{17}$ The same applies to refugees. However, they are often under pressure to perform direct contacts to employers because they rarely use services of the National Employment Agency. They either have little information about rights and options that the state agency is offering or they hesitate to register. This is particularly the case when they have not yet obtained citizenship, although citizenship is not a prerequisite for entering the informal labour market. In addition, they also lack information on their beneficiary rights when registered at the Agency (i.e. concerning health care, social protection, subsidies in transportation, etc).

The latest empirical research ${ }^{18}$ showed strengthening of their informal ties to the local population, particularly when searching a job, as well as their willingness to broaden relations to domiciles (some 36 per cent have opened up ties to both fellow friends and local citizens). At the same time, surveys no longer demonstrated statements showing intolerance toward them on the part of the local population. This appears to prove that the process of their final integration is under way.

In conclusion, we can say that refugees face great obstacles in transforming their cultural capital (high level of education and professional skills) into economic capital, which is the main cause of their getting along poorly, weak social connectedness, and still low social capital (informal networks to local citizens). The main reasons are immense difficulties in accessing the labour market and structural challenges (delayed post-socialistic transformation, high overall unemployment rate, etc.).

\section{Refugee Emigrations: Mixture of Economic and Humanitarian Incentives}

A certain number of other empirical studies have shown that emigration to the developed West (the EU, Canada, Australia, and the US) was one of the prevalent "coping strategies" for forced migrants. It was somewhat easier for these people to apply for entry during the Balkan crisis in the nineties. However, not only were the younger generations prone to the strategy of "escapism," but so were those who had already established ties to foreign countries and those who found themselves in foreign countries at the onset of the war in the former Yugoslavia (descendants of older economic emigrants, those already having established business contacts, etc.).

Another qualitative-case study of former Yugoslav refugees in England was carried out comparatively on two sub-samples: persons who got asylum in Oxford, UK, and those who fled to Serbia. ${ }^{19}$ In-depth analysis indicates the clear economic "pull" factors of emigration-better chances for improving living conditions in comparison to those who went to Serbia. However, the refugees, residing in the UK claimed that although their quality of life was improved owing to the welfare state, ${ }^{20}$ they were also generally socially excluded. Due to inability to attain employment that would match their qualifications, they were confronted with additional difficulties, such as inaccessibility of a variety of beneficial services (medical care, education, culture, and informal ties to the domestic population).

Furthermore, refugees staying in England also had low social capital. They were rarely getting along with either previous generations of economic migrants or the host English population. Even their contacts with relatives in Serbia were rare. Thus, social ties were reduced to an extremely narrow circle of close people and fellow friends. Nevertheless, such a situation leads to social exclusion and, finally, self-isolation.

When it comes to future prospects, it came as no surprise that most of the middle-aged and older people with asylum in England intended to return to Serbia, mainly to Vojvodina, ${ }^{21}$ after they accumulate savings in order to afford some real estate (a house with a piece of land).

Having summarized the optimal solutions for the forced migrants' status, some practical measures were suggested. First and most important is dual citizenship for each person who chooses to permanently settle in Serbia. This would enable refugees and displaced persons to get full citizenship

(C) Mirjana Bobic, 2009. This open-access work is licensed under a Creative Commons Attribution-NonCommercial 4.0 International License, which permits use, reproduction and distribution in any medium for non-commercial purposes, provided the original author(s) are credited and the original publication in Refuge: Canada's Journal on Refugees is cited. 
status and all due rights: freedom of movement, work, medical care, education, and political and other rights. Refugees' repatriation should also be encouraged, and this is especially important for the elderly, since their most important issue is the regularity of payments of their pensions from the places of their earlier residence (in former Yugoslavia).

\section{Internally Displaced Persons (IDPs)}

Unlike refugees, the total number of internally displaced persons in Serbia is decreasing too slowly. The first group of 225,738 persons left Kosovo and Metohija in 1999, following the withdrawal of the Yugoslav Army and security forces. Afterwards, an additional population of 4,200 persons left in spring 2004, after the series of violent acts of majority Albanians against ethnic minorities (non-Albanians) and international government (UNMIK) in the province. In future, one could expect further outflows of non-Albanians due to the claimed independence of Kosovo in March 2008.

Their actual total number is 206,504 (Table 3). According to the latest figures (2007), gender structure is almost equal. The workforce contingent (age 18-59) prevails, again without specific gender imbalances. One out of six is the elderly, with females dominating slightly, while the share of babies and the youth (age $0-17$ ) is 11.3 per cent.

Table 3. IDPs in Serbia and Montenegro age and gender structure, 2007*

\begin{tabular}{|c|c|c|c|c|c|c|}
\hline age & M & $\%$ & $\mathrm{~F}$ & $\%$ & Total & $\%$ \\
\hline $0-4$ & 440 & 0.2 & 378 & 0.2 & 818 & 0.4 \\
\hline $5-11$ & 11246 & 5.4 & 10651 & 5.2 & 21897 & 10.6 \\
\hline $12-17$ & 12431 & 6.0 & 11609 & 5.6 & 24040 & 11.6 \\
\hline $18-59$ & 62293 & 30.2 & 61691 & 29.9 & 123984 & 60.0 \\
\hline $60+$ & 15975 & 7.7 & 19790 & 9.6 & 35765 & 17.3 \\
\hline Total & 102385 & 49.5 & 104119 & 50.5 & 206504 & 100 \\
\hline
\end{tabular}

Source: http://www.unhcr.org.yu/utils/File.aspx?id=237 (accessed October 2009).

As for ethnic structure, most of them are Serbs (68 per cent), then Roma (12 per cent), and Montenegrins (8 per cent) ${ }^{22}$ They live mainly in private accommodations (93 per cent), and about 7 per cent are located in collective centres. In 2002 there were about 550 collective centres in Serbia and Montenegro. However, in 2002 the procedure of their planned closure was launched. By the end of 2005 there were 278 centres, out of which 99 were official, while the rest were unofficial, with almost none of the refugees and a decreasing share of IDPs. According to the last UNHCR report, there are only 80 collective centres (62 are situated in Serbia and 18 in Kosovo). They accommodate 6,748 persons (1,702 refugees and 5,046 IDPs). ${ }^{23}$

When the quality of life is considered, this population is not only below the poverty line on a social scale or slightly over it, but is also extremely poor and at the very edge of society. Beside lacking regular income, they also lack suitable business opportunities. A survey carried out by international institutions on the sample of 1,400 people accommodated in Serbia showed that 52 per cent are unemployed, 14.4 per cent are working in the public sector, which often means that their job is just fictional (without payment or underpayment), 10 per cent are employed in private firms, and 5.5 per cent are engaged in seasonal jobs. There are 18.5 per cent of supported persons, out of whom 7.3 per cent are students and 11.2 per cent are retired. Their work is underpaid and consequently accompanied with the intense feeling of constant humiliation. There was the evidence of wages of only 1 DEM per day. ${ }^{24}$

Although formally "citizens" of Serbia, IDPs are restricted in claiming their basic human rights. Experiencing gross violations of their civil rights on an everyday basis makes them de facto "quasi citizens" of Serbia.

Since they rarely succeed in getting their residence in Serbia, their freedom of movement is restricted. This happens because the Serbian authorities imply that their homeland is in Kosovo, and that they will surely return there. That's why they are issued "temporary residence permits" that are valid for three months only, that would have to be prolonged afterwards. There are a lot of reports of cancellations of these documents for those who had to change their place of residence in Serbia or had to visit Kosovo. Thus not only do they suffer violations of freedom of movement, but also the essential right to choose a place to live.

Another problem concerning IDPs is claiming personal identification rights (obtaining identity cards, passports, working booklets). Basically, they have the right to gain new identity cards in Serbia, but in an attempt to obtain them, they have to provide a variety of documents/certificates on residence, birth, marriage, and citizenship. In order to have these issued, they often have to travel to the various local offices and archives that are relocated to different places in southern Serbia, once they have been displaced from Kosovo. That makes huge impediments for IDPs due to the necessity of making several trips, not only to apply for the documents, but also aquire them later on, which is hardly affordable by the majority of refugees.

IDPs have similar problems with working booklets. These documents can be obtained only in the firms or companies where they previously worked, while it is almost impossible to reach them from private companies at Kosovo. 
Ex-employees from the public enterprises out of Kosovo are in a somewhat better position. They are able to get these certificates and utilize their pension rights more easily, for the appropriate records have been transferred to Serbian municipalities. The lack of work booklets prevents one from realization of the right to support oneself and receive social care, if necessary.

Another example of gross violation of their civil rights is medical care. With their health endangered, IDPs are a very sensitive group in this respect-76 per cent of them have chronic diseases that require long medical treatment. Alcoholism and psychosocial symptoms related to war traumas are also frequently present. Some 8 per cent of children suffer from partial or total exhaustion, and no less than 17. 2 per cent from stunted growth. ${ }^{25}$ However, regardless of these facts, refugees have the right to be treated in primary and urgent medical care only, while for all other kinds of services, they are obliged to pay instantly. In terms of their general situation, it is clear that they cannot bear the costs of any medical treatment, which additionally contributes to further worsening of their already damaged health.

Social security rights are another field of great risk for IDPs. If one has a job in Serbia, whether it is paid or not, or if he/she has any private property (including Kosovo), he/she cannot apply for aid. According to the statistics of the Ministry of Social Security, less than 10 per cent of the population in Serbia receive benefits of social protection, although a survey on poverty carried out in 2001 demonstrated that one-quarter of internally displaced persons live at or under the poverty line (in terms of more than $\$ 1$ per capita). ${ }^{26}$

The problem of property rights is also a very sensitive one. Despite the fact that many of the displaced persons have their property left in Kosovo, they are not able to access it. At the same time, they are unable to obtain aid for solving their housing problems as long as they live in Serbia or unless they are included in some large-scale repatriation programs.

Roma IDPs are in an even worse social position. They are at the very bottom, not only within this group, but in the overall society as well. The vast majority of them are located in collective centres or in slums of the cities and its outskirts. With many children (due to predominantly high fertility), elderly, large families, mostly unemployed, sick and disabled persons, they are almost completely marginalized. The level of education is low and children usually do not attend school. Their main income comes from begging and some kind of trade.

Regarding their future plans and perspectives, IDPs are in a very dubious situation. Contemporary Serbian authorities do not recognize Kosovo as an independent state (as unilaterally claimed in March 2008). Thus, they claim their return to the province, while the people affected do not believe in the sustainability of such a solution, particularly due to the absence of the Serbian army and police in Kosovo. In fact, despite the presence of international armed forces in the province (UNMIK), the primary reason for their fears and anxiety is lack of security and freedom of movement for Serbs and non-Albanians.

\section{Policy: Strategic Documents and Perspectives}

The Serbian government adopted three main documents that are the basis for integration of refugees from ex-Yugoslav republics. These are: National Strategy for Resolving the Problems of Refugees and IDPs, the Poverty Reduction Strategy, and the "Road Map."

In May 2002, the Serbian government adopted the National Strategy for Resolving the Problems of Refugees and Displaced Persons, with the support of the international and local stakeholders (UNHCR, UNDP, UNOCHA, NGOs, etc). The main goal aims at providing conditions in two broad directions: (1) repatriation and (2) local integration of refugees from Croatia and Bosnia-Hercegovina (according to their personal choice). Starting from the empirical evidence (surveys and interviews) which demonstrated the will of the majority of them to stay in Serbia, the integration into local settings was posed as the most desirable and durable solution. In that sense, the existing document (National Strategy) strives to facilitate the process. The strategy has well-developed schemes for ameliorating problems of housing, employment, property and legal status issues, security, and safety; and durable solutions for those accommodated in collective centres that are to be closed (those are the most vulnerable groups - the elderly, lone parents, mostly females, children without parents, sick people, the unemployed, and others unable to take care of themselves). However, the principle challenge of the implementation of the strategy is the great financial resources required, on the side of Serbian government and foreign funding, the latter being significantly reduced in 2003 and $2004 .^{27}$

The Poverty Reduction Strategy Paper was adopted by Serbian government in 2003. Its basic goal was social end economic recovery of the country, with special attention paid to reducing huge overall poverty and vulnerable groups (like refugees and IDPs). Unfortunately, up to this date, it has stayed mostly unrealized, for the same reasons as the previously mentioned action plan, which is, actually, the complementary one. The second reason is the institutional gaps in development of the projected instruments.

In 2003 there was some political progress towards normalization of relationships between the neighbouring Balkan states, and henceforth a gradual improvement of certain 
conditions for repatriation. A bilateral agreement between Serbia-Montenegro and Bosnia-Herzegovina was signed, and a visa regime with Croatia was abolished. The regional initiative called the "Road Map" was launched, aimed at finding long-term solutions by 2006 for all forced migrants in new Balkan states, derived out of former Yugoslavia. It was encouraged by the UNHCR, The Organization for Security and Cooperation in Europe OSCE, and the European Commission. On January 31, 2005, in Sarajevo the declaration on the regional resolution of the problems of refugees and displaced persons was signed (except those from Kosovo and Metohija), by the ministers of three states: Bosnia-Hercegovina, Serbia and Montenegro, and Croatia. The Road Map assumed a joint matrix of national action plans directed at repatriation or integration among the three signatory countries. Up to now, there have been only two chapters of joint implementation action created, one concerning common statistics and another related to access to basic human rights. Concerning these issues, it should be stated that the return shares are very low-in most cases persons who decided to repatriate to Croatia and Bosnia were pushed to return to Serbia after a while, for their homes were either destroyed, or repossessed, and their safety was jeopardized. So, the return to Bosnia-Hercegovina in 2005 was even twelve times less compared to 2002. The decreasing number of returns might be caused by the fact that it was the most difficult cases that remained to be solved.

Speaking of Croatia, officials report that there are 122,000 Serbs returnees, while the association of Croatian Serbs and the OSCE mission estimate the real number as being much lower. Furthermore, they assess that 60 to 65 per cent of Serbs have actually returned to Serbia, Montenegro, and Bosnia-Hercegovina after a short stay, due to unresolved issues: tenancy/occupation rights, restricted access to property, unregistered working hours (in the period 1991-1995 in Croatia), problems in claiming retirement rights, and low levels of safety and security.

As to IDPs, in 2006 the Serbian government and UNMIK signed the Protocol on Sustainable Returns, declaring freedom of settlement in places that might not be their original places of residence. Unfortunately, very few succeeded in returning to Kosovo, only 650 , due to uncertain conditions at the ground, employment difficulties, restricted freedom of movement and security risks, continuing impunity and weakness of the rule of law, and also discriminatory practices toward them.

\section{Final Comments}

This short overview has been intended to demonstrate the vulnerability of these two social groups of forced migrants and, as well, the complexity and diversity of practical actions that are undertaken in finding sustainable solutions. The very fact of the declining number of refugees does not necessarily mean that they are either repatriated or integrated into local society. On the contrary, it is very often the case that their humanitarian status has been cancelled and thus they were actually transferred to the poor domicile population, falling at the bottom line of the social ladder. The vast majority of them are fully socially excluded (the elderly, the sick, the unemployed, those with special needs, women, children, lone parents, those accommodated in collective centres, etc.).

Although a majority of refugees opted for and received Serbian citizenship, it didn't bring them much improvement in social status. Despite their relatively better educational background, their unemployment rate is even greater than among the local population, and their access to health care and to social and protective services is hampered. This is due to the hardships of social transformation of Serbian society into the market economy and, consequently, low economic growth and overall political advancement, including the accession to the European Union and global institutions.

It is a fact that there are very detailed action plans developed to facilitate the integration of refugees, while the political status of IDPs is very complicated and, thus, vague. However, there are two types of impediments to the process of integration of refugees and IDPs: legal framework and lack of sufficient revenues.

The current legal framework prevents claiming of basic human rights, because it is based on the right to reside on certain territory, and does not take into account the vulnerability and reality of everyday life of these individuals. Secondly, the Serbian government has adopted very detailed strategies and signed agreements with neighbouring states on long-term solutions of either repatriation or local integration. Up to date, not much has been done in the area of repatriation, especially due to the lack of bilateral agreement concerning the most vulnerable refugees, former tenancy right holders, and elderly citizens. The risks of local integration into Serbian society are related to overall stalled social transformation and economic recovery, i.e., lack of financial resources that would boost the otherwise very developed schemes in housing, income generating projects, women's employment, education, improved medical care, social protection of the disabled, the elderly, and the sick, etc.

The uniqueness of the IDPs must be particularly emphasized. The fact that Serbian government does not recognize the independence of Kosovo province, which has been unilaterally claimed by local Albanian authorities in March 2008, places the vast majority of non-Albanians who remained there, as well as those who have settled in Serbia, in a very complicated position. Namely, those who stayed in Kosovo

(C) Mirjana Bobic, 2009. This open-access work is licensed under a Creative Commons Attribution-NonCommercial 4.0 International License, which permits use, reproduction and distribution in any medium for non-commercial purposes, provided the original author(s) are credited and the original publication in Refuge: Canada's Journal on Refugees is cited. 
live in enclaves, isolated, socially excluded, frightened about their safety and their children's safety and future. For those who stayed in Serbia, the plans of repatriation and return to Kosovo seem to be fading, while the officials still "manipulate" their destiny in unsuccessful political negotiations, not being ready to give up the political struggle to return the province to Serbian sovereignty.

\section{Notes}

1. According to the relevant resources (UNHCR office in Belgrade), in 2009 the number of registered refugees in Serbia has been 86,336 , which is seven times less comparing to their peak in 1996. The decrease has been facilitated due to four main channels: local integration (around 200,000 have obtained Serbian citizenship), returns (150,000 have returned to the countries of origin in the region), emigration to the West $(46,000)$, while some of them died in exile $(40,000$, Human Rights of Refugees, Internally Displaced Persons, Asylum Seekers and Victims of Trafficking in Serbia and Montenegro, Report, <http://www.grupa484.org.yu >)

2. According to the UNHCR report, at the climax of armed conflicts among ex-Yugoslav nations in 1993, there have been around 2.5 million refugees and displaced persons in the region, which made up to one-fifth of the total forced migrants in the globe (15 million); Nada Raduski (Belgrade: CDI IDN, 2001; Ekonomski Institut, 1996).

3. The "eastern model" of nation building is, predominantly, related to sentiments of common territory, blood ties, genealogies, population movements, vernacular languages, tradition and customs, thus implying a group's homogenity, whereas the "western" one is related to legal and political community, citizenship, egalitarianism, liberty and democracy, civil culture, thus heterogenity; Saša Nedeljković, Čast, krv i suze (Belgrade: Zlatni zmaj /Odeljenje za etnologiju i antropologiju Filozofskog fakulteta, 2007).

4. Vladimir Ilić, Manjine $i$ izbeglice u Vojvodini (Belgrade: Helsinški odbor za ljudska prava u Srbiji, 2001).

5. Mirjana Bobić, "Migracije," in Studije o Izbeglištvu, ed. Ivan Milenković et al. (Belgrade: Grupa "484," 2006; Mirjana Bobić, Demografija i Sociologija: Veza ili Sinteza (Belgrade: Službeni Glasnik, 2007).

6. David J. Whittaker, Asylum Seekers and Refugees in the Contemporary World (London and New York: Routledge, 2006).

7. Ibid., 2

8. Guiding Principles on Internal Displacement, Introduction, para. 2, <http://www.internal-displacement. org/8025708F004D404D/(httpPages)/CC32D8C34EF93C 88802570F800517610> (accessed September 30, 2009).

9. In order to save space, I will not present the tables; but I will refer to data that I have already published in my article; see Bobić, "Migracije," 2006.
10. Mirjana Bobic, "Refugees and Internally Displaced Persons in Serbia: Statistics, Quality of Everyday Life, Social Capital, Coping Strategies, Policies," in Migrations, Crises and Recent Conflicts in the Balkans, ed. Alain Parant (Greece: LADS, University of Thessaly Press, 2006), 141-153.

11. Ibid.

12. However, some reports showed that refugees were not bound to remain on the social margin. According to an expert evaluation, the refugees brought to Serbia 2 to 6 billion euros of fresh capital (from savings, sale of their houses, apartments, properties) that could have been utilized in privatization projects; Djuric, Zvezdan, "Propuštena šansa," Politika 5 (October 2004).

13. It was realized with the assistance of the UNDP office in Belgrade; see M. Babović, S. Cvejić, and D. Rakić, Position of Refugees in the Labour Market and Their Inclusion in Active Labour Market Policies (Belgrade: NGO Group “484," 2007).

14. Vladimir N. Cvetković, Strah i poniženje: Jugoslovenski rat $i$ izbeglice u Srbiji 1991-1997 (Belgrade: Institut za evropske studije, 1998).

15. Jelena Vlajković et al., Psihologija izbeglištva (Belgrade: Žarko Albulj, 2000).

16. However, more than half of the interviewees ( 56.5 per cent) had no permanent and stable social relations (low social capital) and, thus, remain in the vicious circle of isolation.

17. Rosalind Edwards, "Overview of the 'Social Capital': Its Relevance and Implications for Local Communities Conference," Sociologija 46, no. 3 (July-September 2004) (Belgrade: Sociolosko drustvo Srbije, 2004); S. Tomanovic, "Families and Social Capital in Serbia - Some Issues in Research and Policy," Sociologija 50, no. 1 (January-March 2008) (Beograd: Sociolosko drustvo Srbije, 2008).

18. Babović, Cvejić, and Rakić „Position of Refugees in the Labour Market and their Inclusion in Active Labor Market Policies (Belgrade: NGO Group 484, 2007).

19. Gordana Vuksanovic, Jugoslovenske izbeglice između želja i mogućnosti za povratak (Novi Sad: Katedra za sociologiju Filozofskog fakulteta, 2001).

20. In some districts in England refugees get support which amounts even to as much as 200 pounds per elder member of a household; in Canada, in the province of Quebec, they get 640 Canadian dollars per member, and in other provinces about 400 Canadian dollars, which is 15 per cent more than the welfare support assigned to the local population.

21. Vojvodina is the more developed part of Serbia, where there is a lot of empty space and homelands lacking descendants, due to lowered fertility and aging.

22. Data are based on the NGO and UNHCR reports, <http:// www.grupa484.org.yu >.

23. World Refugee Survey - Serbia Submission, draft (Belgrade: Group 484, January 2008).

24. Kosovo IRL, "Situacija, problemi, rešenja?" (unpublished, Belgrade: Grupa 484, 2002). 
25. Ibid.

26. According to some foreign humanitarian organizations, no less than 90 per cent live under the poverty threshold.

27. It has been estimated that the implementation of the strategy would cost 620 million dollars, 460 million of which are expected from foreign donations.

Mirjana Bobic, Ph.D., is an associate professor in sociology and demography at the University of Belgrade, Serbia. She published two books and many peer reviewed articles at home and abroad. This article is part of the research "Social Actors and Social Change in Serbia 1990-2010" (149005 B), funded by Ministry of Science of the Republic of Serbia, carried out at the Institute for Sociological Research, Faculty of Philosophy, Belgrade. Its main parts were presented at the Conference "Refugees and Insecure Nation: Managing Forced Migration in Canada," held at York University, Toronto, June 15-18, 2008. The author's participation at the Conference was cofunded by Ministry of Science of the Republic of Serbia and the Centre for Refugee Studies, York University. 